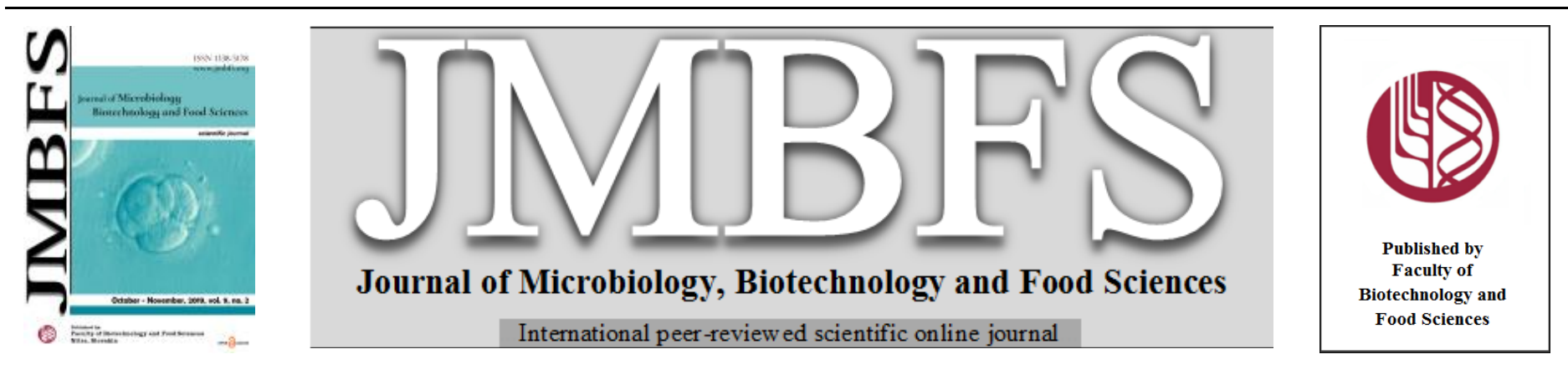

\title{
OPTIMIZATION OF THE CULTURE MEDIUM COMPOSITION TO INCREASE THE BIOSYNTHESIS OF RECOMBINANT HUMAN INTERLEUKIN-7 IN ESCHERICHIA COLI
}

\author{
Valentyna Motronenko ${ }^{* 1}$, Tetiana Lutsenko ${ }^{1,2}$, Alexander Galkin ${ }^{1,2}$, Yuriy Gorshunov ${ }^{3}$, Valentyna Solovjova ${ }^{4}$ \\ Address(es): Valentyna Motronenko \\ ${ }^{I}$ Igor Sikorsky Kyiv Polytechnic Institute, Department of Translational Medical Bioengineering, Peremohy av., 37, 03056, Kyiv, Ukraine. \\ ${ }^{2}$ UA "PRO-PHARMA" LLC, Department of Research and Development, Peremohy str., 9, 03170, Kyiv, Ukraine. \\ ${ }^{3}$ Scientific, Design and Technological Institute of Urban Economics, Metropolitan Basil Lypkivskyi str., 35, 03035, Kyiv, Ukraine. \\ ${ }^{4}$ State Research Center for Food Hygiene, Chyhorina str., 18, 01042, Kyiv, Ukraine.
}

*Corresponding author: tmb@kpi.ua

doi: 10.15414/jmbfs.2020.9.4.761-768

ARTICLE INFO

Received 27. 5. 2019

Revised 5. 9. 2019

Accepted 11. 9. 2019

Published 3. 2. 2020

Regular article

open $\mathcal{O}_{\text {Access }}$

\begin{abstract}
The purpose of the work was to rise of biosynthesis of the human recombinant interleukin-7 (rIL-7) in E. coli by optimizing the quantitative and qualitative composition of the culture medium. As a result of optimization of the quantitative composition of organic and mineral components of the culture medium using the matrix of planning a fractional factor experiment, it was possible to increase the synthesis of rIL-7 by 1.3 times. It was proved that the use of supplements to the culture medium in the form of extracts of Clivia miniata and Zephyranthes grandiflora (0.5-1.0\%) stimulated the rIL-7 synthesis in recombinant bacterial cells in 1.3-1.4 times. The use of phytoextracts at a concentration of 5.0\% and more caused an inhibitory effect on the producer biosynthetic properties. It has been established that the modulation of the biosynthetic activity of recombinant bacteria is due to the interaction of the biologically active substances of plant extracts with the surface structures of the bacterial cell, namely, porins (OmpC and OmpF proteins). The stimulating effect of vitamin $\mathrm{K} 1$ (15-25 mg per $1 \mathrm{ml}$ of culture medium) in the liposomal form was proved; such approach allowed increasing the synthesis of rIL-7 in 1.34-1.39 times. And the use of liposomal form of plant extracts as an approach to increasing the bioavailability of biologically active substances is not appropriate.
\end{abstract}

Keywords: recombinant human interleukin-7, Clivia miniate, Zephyranthes grandiflora, vitamin K1, biosynthesis

\section{INTRODUCTION}

Optimization of biosynthesis processes of recombinant medical products is an actual problem of biotechnology. The importance of this task increases in terms of economic assessment of the relevant biotechnology. Since the yield of the target products, especially in cases of multi-stage purification procedures of recombinant proteins for therapeutic purposes, has a critical effect on the cost of developed medicines and, accordingly, on their social availability. It should also be noted that such drugs are commonly used for the treatment or prevention of seriously curable diseases (in particular oncological, autoimmune, and infectious diseases) (Pererva et al., 2012; Semenyuk et al., 2018).

One of the directions of increasing the yield of recombinant products in bacterial biosynthesis systems is optimizing of culture media composition. An analysis of available publications on the biosynthesis of recombinant cytokines and other proteins in the Escherichia coli expression system suggests that the most commonly used are standard mediums LB, YT and TB, as well as similar peptone-containing mediums (Sengupta et al., 2008; Ahmed et al., 2018; Zhong et al., 2014; Galkin et al., 2017; Pal et al., 2018; Khalilzadeh et al., 2004; Adinarayana et al., 2002; Lutsenko et al., 2015). However, in many cases, researchers separately add different mineral salts and organic compounds in various concentrations (Ahmed et al., 2018; Galkin et al., 2017; Galkin et al., 2017; Pal et al. 2018; Khalilzadeh et al., 2004; Lutsenko et al., 2015), as well as vitamins and vitamin-like substances (Omotani et al., 2017; Galkin $\boldsymbol{e t}$ al., 2015; Wang et al., 2014). In most cases, the authors do not provide experimental data that would confirm the substantiality of using the qualitative and quantitative media composition. Various methodological approaches may be used to determine the optimal composition of culture media, however, the most commonly used are the Box-Wilson method, complete and fractional factor experiments (Adinarayana et al., 2002; Boiko et al., 2018; Wang et al., 2009; Singh et al., 2017). In the case of a fractional factorial experiment (FFE) there is a possibility to reduce the number of experiments due to the correlation between the columns of the matrix of planning, which complicates this stage, but does not affect the validity of the estimates of the experiment. Therefore, given the literature (Adinarayana et al., 2002; Boiko et al., 2018; Wang et al., 2009; Singh et al., 2017) and the results of our own previous experiments on the biosynthesis of recombinant proteins in E. coli (including recombinant interleukin-7, rIL-7) (Galkin et al., 2015), the concept of FFE is quite acceptable. The works of various authors testify to the possibility of effective application of plant extracts as growth stimulators of bacterial cells, as well as the synthesis of bacteria of certain products, including recombinant proteins (Pererva et al., 2012; Galkin et al., 2015; Pererva et al., 2012). In our previous studies, stimulating effect on the growth of recombinant E. coli bacteria and the biosynthesis of the recombinant heat shock protein HSP-60 of Chlamydia trachomatis was shown for the extracts of two plants of the Amaryllidaceae family - Clivia miniata and Zephyranthes grandiflora (as a supplement to the culture medium in range of $0.5-1.0 \%)$. The literature describes the possibility of stimulating the growth of shigella and staphylococcus when the vitamin K1 added to culture medium (Galkin et al., 2015). The analysis of the above literary sources led us to the idea of the expediency of evaluating the application of extracts of such plants in the culture medium when cultivating $E$. coli to increase the yield of rIL-7 of the following supplements: the extracts of Clivia miniata and Zephyranthes grandiflora, as well as vitamin K1.

The aim of the work was to optimize the composition of the culture medium through the use of minerals and organic compounds, studying the influence of Clivia miniata and Zephyranthes grandiflora extracts on the level of biosynthesis of recombinant interleukin-7 by E. coli bacteria, as well as studying possible mechanisms of interaction of plant substances with a bacterial cell.

\section{MATERIALS AND METHODS}

\section{Preparation and evaluation of plant extracts}

Extracts of following plant parts were prepared: rhizomes, roots and leaves of cloves of natal lily (Clivia miniata), bulb of pink rain lily (Zephyranthes grandiflora). Plant raw material was ground to particles in the size of 3-5 mm using a laboratory mill LZM-1 (Olis Ltd., Ukraine). The extract was prepared 
using ratio of raw material: the extractant (ethyl alcohol 40\%) is 1:5. Extraction was carried out at room temperature by fractional 2-step maceration, with the duration of each extraction cycle of $12 \mathrm{~h}$. Upon receipt, the evaporation of the extract was performed using a vacuum rotary evaporator at a temperature of 40 ${ }^{\circ} \mathrm{C}$ to the dry residue and dissolved with distilled water to the initial volume. Determination of the protein in the extracts was carried out by biuret method (Galkin et al., 2015). Quantitative content of polysaccharides in extracts was carried out using the gravimetric method (Galkin et al., 2011), the content of flavonoids (in terms of routine) - by the spectrophotometric method (Lomboeva et al., 2008), and the content of alkaloids (in terms of lycorine) - by the photometric method (Galkin et al., 2015).

\section{Liposomes obtaining}

Preparation of liposomes was carried out by hydration of the lipid film, followed by extrusion by (Campani et al., 2014). An organic solution $\left(\mathrm{CHCl}_{3}: \mathrm{CH}_{3} \mathrm{OH}=\right.$ 2:1) containing soy phosphatidylcholine (SPC) was dried in a round bottomed glass bulb using a rotary evaporator under nitrogen for about $20 \mathrm{~min}$ at $110 \mathrm{rpm}$ and at a temperature of $30^{\circ} \mathrm{C}$. Vitamin $\mathrm{K} 1$ and plant extracts were added to the organic solution at concentration $125 \mu \mathrm{g}$ per $1 \mathrm{mg}$ of SPC. The resulting lipid films were then rehydrated in the presence of glass beads containing phosphate buffered saline (PBS), pH 7.4. The resulting suspension was passed five times through polycarbonate membranes with reduced porosity $(0.4,0.2$, and $0.1 \mu \mathrm{m})$ using a thermo plate extruder. In conclusion, the liposomes were purified by molecular-excite chromatography with Sephadex G-50 (Sigma, USA) to remove uncapsulated vitamin $\mathrm{K} 1$ or extracts.

\section{Culture medium and its optimization by FFE}

LB medium $(0.5 \%$ yeast extract, $1.5 \%$ peptone, $0.5 \% \mathrm{NaCl})$ was used in the work; antibiotic chloramphenicol $(50 \mu \mathrm{g} / \mathrm{ml})$ was added to the medium Optimization of the culture medium was carried out as follows. In the case of the dependence of the end result on many factors, the FFE is used, which is a fraction (fractional replicas: $1 / 2,1 / 4,1 / 8$, etc.) from the full factor experiment. The results of experiments were presented in a linear form and described by the regression equation

$y=b_{0}+b_{1} x_{1}+b_{2} x_{2}+\ldots+b_{n} x_{n}$

where $\mathrm{n}$ - number of experiments

Calculation of coefficients was carried out according to the formula

$$
b_{i}=\frac{1}{N} \cdot \sum_{u=1}^{N} x_{i u} \cdot \bar{y}_{u}, i=1,2, \ldots, n,
$$

where $\bar{y}_{u}-$ mean value for parallel experiments of the $i$-th line of the matrix of planning, calculated by the formula

$$
\bar{y}_{u}=\frac{1}{m} \cdot \sum_{k=1}^{m} y_{u k},
$$

where $m$ - number of parallel experiments

Properties of such a matrix of planning allow calculating the regression coefficients independently of each other by the results of all studies.

When preparing the nutrient medium, the components were added in a different form. Thus, lactose, glycerol and glucose were added to the nutrient medium in the form of a complex 5052 solution containing $10 \%$ lactose, $25 \%$ glycerol and $2.5 \%$ glucose (Studier, 2005);

D-maltose - in the form of $10 \%$ solution, ammonium sulfate $\left(\mathrm{NH}_{4}\right)_{2} \mathrm{SO}_{4}$ as $0.5 \mathrm{M}$ solution; potassium dihydrogenphosphate $\mathrm{KH}_{2} \mathrm{PO}_{4}$ as $1 \mathrm{M}$ solution; sodium hydrophosphate $\mathrm{Na}_{2} \mathrm{HPO}_{4}$ as $1 \mathrm{M}$ solution.

\section{Expression of recombinant protein}

The biosynthesis of rIL-7, $17.4 \mathrm{kDa}$ protein, was carried out in E. coli bacterial system. The expression system was constructed using plasmid pACYC184 (Thermo Scientific, No. X06403) and E. coli BL21 (DE3) strain (GE Healthcare, 27-1542-01). The cells of this strain have a T7 phage RNA polymerase gene, which is integrated into the bacterial chromosome in the $\lambda$ D69 vector. It can be expressed under the transcriptional control of the lactose promoter promoter.

The protein synthesis was carried out by recombinant strain fermentation in the medium of the following composition: peptone, yeast extract, $\mathrm{MgSO}_{4} \times 7 \mathrm{H}_{2} \mathrm{O}$ $\left(\mathrm{NH}_{4}\right)_{2} \mathrm{SO}_{4}, \mathrm{KH}_{2} \mathrm{PO}_{4}, \mathrm{Na}_{2} \mathrm{HPO}_{4}$, lactose, glycerol, glucose, D-maltose, $\mathrm{NaHCO}_{3}$, and chloramphenicol at the temperature of $38{ }^{\circ} \mathrm{C}$ with orbital swinging from speed $160 \mathrm{rpm}$ within 14-18 h, which made it possible to get high yields of the target protein. At the end of the incubation, the cells were precipitated by centrifugation at $4000 \mathrm{rpm}$ within $15 \mathrm{~min}$.

\section{Electrophoresis and densitometry}

Electrophoretic analysis of biomass and proteins was carried out in $15 \%$ polyacrylamide gel (PAAG) in the presence of $1 \%$ sodium dodecyl sulfate in the tris-tritsinovoy buffer system. Scanning of colored PAAG and the calculation of the target protein content were determined using TotalLab 1.10 software.

\section{Bacteriophages}

The following bacteriophages were used in the work: T7, $\lambda, \mathrm{Ox} 2$, Ox $2 \mathrm{~h} 12$, TuIb and T2. The efficiency of bacteriophages seeding in the presence of extracts (experiment) in comparison with control (seeding without extracts) was determined by counting negative colonies on Petri dishes. In an experimental variant, extracts in a volume of $0.1 \mathrm{ml}$ were introduced into $5.0 \mathrm{ml}$ of molten top layer; $0.1 \mathrm{ml}$ of phage and $0.1 \mathrm{ml}$ of $E$. coli liquid culture, stirred and poured into a cup with a lower layer of $1.8 \%$ agarized LB medium. In the control variant, the seeds were done in the same manner, but instead of the extract, $0.1 \mathrm{ml}$ of saline $\mathrm{NaCl}$ was injected. The results of crops were taken into account the next day.

The results of the experiments were statistically processed on the basis of generally accepted methods using some principles of dispersion analysis (Spaepen et al., 2007). The statistical significance of differences between data groups was estimated by the Student's t-test and the F-test, using the expression for Fisher's criterion:

$F_{d}=\frac{\left(M_{1}-M_{2}\right)^{2}\left(n_{1}+n_{2}-2\right)}{C_{1}+C_{2}} \cdot \frac{n_{1} n_{2}}{n_{1}+n_{2}}$

where $F_{d}$-criterion of difference reliability by Fischer; $M_{1}$ i $M_{2}$-average for two samples; $n_{1}$ i $n_{2}$ - the volume of the first and second sample; $C_{1}$ i $C_{2}$-random (intragroup) dispersion in a single-factor disperse complex, the sum of squares of central deviations of dates $(V)$ from its partial average $M_{1} C_{2}=\sum\left(V-M_{i}\right)^{2}$. Calculated value of Fisher's criterion $F_{d}$ compared with standard values $F_{s t}$, which was found using special tables for two degrees of freedom, the first of which is always equal to $\left(V_{l}=1\right)$, and the second is the sum of volumes of two samples minus two $\left(V_{2}=n_{1}+n_{2}-2\right)$.

\section{RESULTS AND DISCUSSION}

\section{Optimization of the culture medium composition}

Optimization of the culture medium by quantitative content of the components was carried out in two stages according to the matrix of the planning of the fractional factor experiment. Initially, the composition of the medium was optimized by the content of organic components - carbon sources: peptone, yeast extract, 5052 solution (lactose $-10 \%$, glycerol $-25 \%$ and glucose $-2.5 \%$ ) and $10 \%$ solution of D-maltose. At the second stage, optimization of the quantitative composition of the mineral substances $\left(\mathrm{MgSO}_{4} \times 7 \mathrm{H}_{2} \mathrm{O},\left(\mathrm{NH}_{4}\right)_{2} \mathrm{SO}_{4}, \mathrm{KH}_{2} \mathrm{PO}_{4}\right.$ $\mathrm{Na}_{2} \mathrm{HPO}_{4}, \mathrm{NaHCO}_{3}$ ) was carried out. In all examine variants of the culture medium, chloramphenicol was added in the same amount. In carrying out experiments to optimize the amount of organic components, inorganic salts were added in amounts corresponding to the basic variant of the nutrient composition (Lutsenko et al., 2015). During conducting experiments on optimization of mineral substances, the number of organic components was determined, which was determined as optimal within the framework of the first stage of the work As the control points, the amount of accumulated biomass of cells (cell concentration was determined by the optical density of the culture fluid) and the yield of recombinant interleukin-7, obtained during the E. coli strain cultivation at the temperature of $38^{\circ} \mathrm{C}$, and the orbital swing from speed $200 \mathrm{rpm}$ within 17 h.

Optimization of the quantitative composition of organic components of the culture medium was carried out using the matrix of the fractional factorial experiment $\mathrm{FFE}^{4-1}$ (table 1). The influence of biomass yield $\left(\mathrm{y}_{1}\right)$ and the synthesis of rIL-7 $\left(\mathrm{y}_{2}\right)$ on the following factors were studied: $\mathrm{x}_{1}-$ peptone, $\mathrm{g} / \mathrm{l} ; \mathrm{x}_{2}$ - yeast extract, $\mathrm{g} / \mathrm{l} ; \mathrm{x}_{3}-$ solution 5052 (lactose $10 \%$, glycerin $25 \%$, and glucose $2.5 \%$ ), $\mathrm{ml} / \mathrm{l} ; \quad \mathrm{x}_{4} \quad 10 \%$ solution D-maltose, $\mathrm{ml} / \mathrm{l}$

For each of the four factors, the variation interval was determined: for the $1^{\text {st }}$ factor $-3-17 \mathrm{~g} / \mathrm{l}$ of peptone; for the $2^{\text {nd }}-10-20 \mathrm{~g} / \mathrm{l}$ of yeast extract; for the $3^{\text {rd }}$ one $-20-40 \mathrm{ml} / \mathrm{l}$ of 5052 solution (glucose $10 \%$, glycerol $25 \%$, glucose $2.5 \%$ ); for the $4^{\text {th }}$ one $-10-50 \mathrm{ml} / 1$ of $10 \%$ D-maltose solution.

Output data for calculating regression coefficients (linear form), when optimizing the composition of the medium for $E$. coli recombinant strain cultivation, are presented in table 1 . 
Table 1 Planning data and results of $\mathrm{FFE}^{4-1}$ for optimization of the organic components content in the culture medium
Factors
Biomass yield, o.u. $\left(\mathrm{OD}_{600}\right)$
Yield of rIL-7, mg/ml

Indexes

\begin{tabular}{llllllll}
\hline & yeast & extract, & solution 5052, \\
$\mathrm{ml} / 1$ & $\mathrm{~g} / \mathrm{l}$ & & $\begin{array}{l}10 \% \text { solution } \\
\text { of D-maltose, } \\
\mathrm{ml} / \mathrm{l}\end{array}$ & Experiment & Theoretic & Experiment
\end{tabular}

\begin{tabular}{|c|c|c|c|c|c|c|c|c|}
\hline $\begin{array}{l}\text { Designation of the } \\
\text { factor }\end{array}$ & $\mathrm{X}_{1}$ & $\mathrm{x}_{2}$ & $\mathrm{x}_{3}$ & $\mathrm{x}_{4}$ & $\mathrm{y}_{1}$ & $\mathrm{y}_{\mathrm{u} 1}$ & $\mathrm{y}_{2}$ & $\mathrm{y}_{\mathrm{u} 2}$ \\
\hline Variable interval & 7 & 5 & 10 & 20 & - & - & - & - \\
\hline Upper level & 17 & 20 & 40 & 50 & - & - & - & - \\
\hline Lower level & 3 & 10 & 20 & 10 & - & - & - & - \\
\hline \multicolumn{9}{|l|}{ Experiments: } \\
\hline $1(\mathrm{~A})^{*}$ & 17 & 20 & 40 & 50 & 1.9 & 1.88 & 0.84 & 0.829 \\
\hline $2(\mathrm{~B})$ & 17 & 20 & 20 & 10 & 1.9 & 1.93 & 0.83 & 0.849 \\
\hline $3(\mathrm{C})$ & 17 & 10 & 40 & 10 & 1.7 & 1.73 & 0.78 & 0.784 \\
\hline $4(D)$ & 17 & 10 & 20 & 50 & 2.0 & 1.98 & 0.86 & 0.849 \\
\hline $5(\mathrm{E})$ & 3 & 20 & 40 & 10 & 1.6 & 1.58 & 0.77 & 0.759 \\
\hline $6(\mathrm{~F})$ & 3 & 20 & 20 & 50 & 1.8 & 1.83 & 0.82 & 0.824 \\
\hline $7(\mathrm{G})$ & 3 & 10 & 40 & 50 & 1.6 & 1.63 & 0.74 & 0.759 \\
\hline $8(\mathrm{H})$ & 3 & 10 & 20 & 10 & 1.7 & 1.68 & 0.79 & 0.779 \\
\hline
\end{tabular}

Legend: Highlights are highlighted in bold; the letters indicate different quantitative compositions of the culture medium

The statistically significant regression coefficients (5\% significance level) of the factors of the FFE model for the $E$. coli strain had the following meanings: for the biomass yield $-b_{0}=1.707, b_{1}=0.014, b_{2}=0.005, b_{3}=-0.008, b_{4}=0.003$; for the rIL-7 synthesis $-b_{0}=0.783, b_{1}=0.003, b_{2}=0.002, b_{3}=-0.002, b_{4}=0.001$.

The equation of the model describing the process of $E$. coli strain deep cultivation on an optimized medium for biomass yield and synthesis of the rIL-7 synthesis, respectively, had the following form:

$$
\begin{aligned}
& \bar{y}_{u 1}=1.707+0.014 x_{1}+0.005 x_{2}-0.008 x_{3}+0.003 x_{4}, \\
& \bar{y}_{u 2}=0.783+0.003 x_{1}+0.002 x_{2}-0.002 x_{3}+0.001 x_{4} .
\end{aligned}
$$

The result of the $\mathrm{FFE}^{4-1}$ regression equation relates the levels of influence of factors with the yield of biomass and the rIL-7 synthesis, respectively, within the studied area. The largest $E$. coli biomass yield [corresponded to 2.0 optical units (o.u.) (experimental) and 1.98 o.u. (theoretical)], and the largest rIL-7 synthesis [0.86 $\mathrm{mg} / \mathrm{ml}$ (experimental) and $0.849 \mathrm{mg} / \mathrm{ml}$ (theoretical)] occurred when using a medium composition $\mathrm{D}\left(x_{1}=17 \mathrm{~g} / \mathrm{l}, x_{2}=10 \mathrm{~g} / 1, x_{3}=20 \mathrm{ml} / 1, x_{4}=50 \mathrm{ml} / \mathrm{l}\right)$. More pronounced effect on the biosynthesis carried out process $\mathrm{x}_{1}$ and $\mathrm{x}_{3}$ factors: concentration of peptone, and 5052 solution (lactose 10\%, glycerol 25\%, and glucose $2.5 \%$ ).

Thus, as a result of optimization using the fractional factorial experiment, adequate equations were obtained describing the amount of accumulated biomass and the synthesized rIL-7 in the deep culture, depending on the quantitative composition of the organic components of the medium. Fig. 1 and 2 show comparison between theoretical and experimental data in terms of biomass and rIL-7 yields.

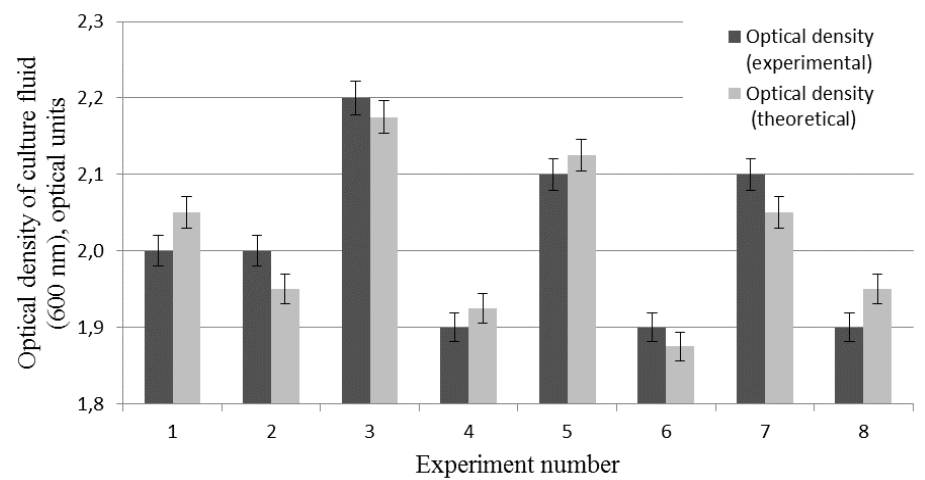

Figure 1 Dependence of the E. coli biomass yield on the quantitative composition of the culture medium (organic components): 1 - composition A; 2 composition $\mathrm{B} ; 3$ - composition $\mathrm{C} ; 4$ - composition $\mathrm{D} ; 5$ - composition $\mathrm{E} ; 6$ composition $\mathrm{F} ; 7$ - composition $\mathrm{G} ; 8$ - composition $\mathrm{H}$

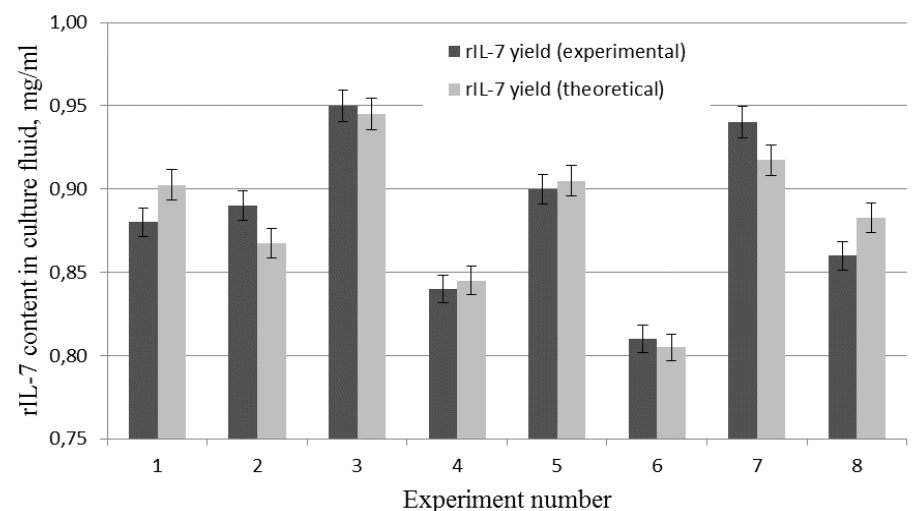

Figure 2 Dependence of rIL-7 yield on the quantitative composition of the culture medium (organic components): 1 - composition A; 2 - composition $\mathrm{B} ; 3$ - composition $\mathrm{C} ; 4$ - composition D; 5 - composition E; 6 - composition F; 7 composition $\mathrm{G} ; 8$ - composition $\mathrm{H}$

Optimization of the quantitative composition of mineral substances of the culture medium was carried out using the $\mathrm{FFE}^{5-2}$ matrix (Table 2). As in the previous case, the effects on the yield of biomass $\left(\mathrm{y}_{1}\right)$ and rIL-7 $\left(\mathrm{y}_{2}\right)$ of the following factors were studied: $\mathrm{x}_{1}-\mathrm{MgSO}_{4} \times 7 \mathrm{H}_{2} \mathrm{O}, \mathrm{g} / \mathrm{l} ; \mathrm{x}_{2}-0.5 \mathrm{M}\left(\mathrm{NH}_{4}\right)_{2} \mathrm{SO}_{4}, \mathrm{ml} / \mathrm{l} ; \mathrm{x}_{3}-1$ $\mathrm{M} \mathrm{KH}_{2} \mathrm{PO}_{4}, \mathrm{ml} / \mathrm{l} ; \mathrm{x}_{4}-1 \mathrm{M} \mathrm{Na}_{2} \mathrm{HPO}_{4}, \mathrm{ml} / \mathrm{l} ; \mathrm{x}_{5}-\mathrm{NaHCO}_{3}, \mathrm{~g} / \mathrm{l}$.

For each of the five factors, the variation interval was determined: for the $1^{\text {st }}$ factor - 3-5 g/l of $\mathrm{MgSO}_{4} \times 7 \mathrm{H}_{2} \mathrm{O}$; for the $2^{\text {nd }}-50-80 \mathrm{ml} / \mathrm{l}$ of $0.5 \mathrm{M}\left(\mathrm{NH}_{4}\right)_{2} \mathrm{SO}_{4}$ solution; for the $3^{\text {rd }}$ one $-30-50 \mathrm{ml} / 1$ of $1 \mathrm{M} \mathrm{KH}_{2} \mathrm{PO}_{4}$ solution; for the $4^{\text {th }}-50-90$ $\mathrm{ml} / \mathrm{l}$ of $1 \mathrm{M} \mathrm{Na}_{2} \mathrm{HPO}_{4}$ solution; for the $5^{\text {th }}-5-9 \mathrm{~g} / \mathrm{l}$ of $\mathrm{NaHCO}_{3}$. Output data for the calculation of regression coefficients (linear form) when optimizing the composition of the medium for cultivating the rIL-7 producer are presented in table 4 (calculation was carried out by the (2) formula). 
Table 2 Planning data and results of $\mathrm{FFE}^{5-2}$ for optimization of the mineral components content in the culture medium

\begin{tabular}{|c|c|c|c|c|c|c|c|c|c|}
\hline \multirow{2}{*}{ Indexes } & \multicolumn{5}{|l|}{ Factors } & \multirow{2}{*}{$\begin{array}{c}\begin{array}{c}\text { Biomass } \\
\left(\mathbf{O D}_{600}\right)\end{array} \\
\text { Experiment }\end{array}$} & \multirow{2}{*}{$\begin{array}{l}\text { yield, } \\
\text { Theoretic }\end{array}$} & \multicolumn{2}{|c|}{ o.u. Yield of rIL-7, mg/m } \\
\hline & $\begin{array}{l}\mathrm{MgSO}_{4} \times \\
7 \mathrm{H}_{2} \mathrm{O}, \mathrm{g} / 1\end{array}$ & $\begin{array}{l}\left(\mathrm{NH}_{4}\right)_{2} \mathrm{SO}_{4}, \\
\mathrm{ml} / 1\end{array}$ & $\begin{array}{l}\mathrm{KH}_{2} \mathrm{PO}_{4}, \\
\mathrm{ml} / 1\end{array}$ & $\begin{array}{l}\mathrm{Na}_{2} \mathrm{HPO}_{4} \\
\mathrm{ml} / 1\end{array}$ & $\begin{array}{l}\mathrm{NaHCO}_{3}, \\
\mathrm{~g} / \mathrm{l}\end{array}$ & & & Experiment & Theoretic \\
\hline $\begin{array}{l}\text { Designation } \\
\text { the factor }\end{array}$ & $\mathrm{x}_{1}$ & $\mathrm{x}_{2}$ & $\mathrm{x}_{3}$ & $\mathrm{x}_{4}$ & $\mathrm{x}_{5}$ & $\mathrm{y}_{1}$ & $\mathrm{y}_{\mathrm{u} 1}$ & $\mathrm{y}_{2}$ & $\mathrm{y}_{\mathrm{u} 2}$ \\
\hline $\begin{array}{l}\text { Variable } \\
\text { interval }\end{array}$ & 1 & 15 & 10 & 20 & 2 & - & - & - & - \\
\hline Upper level & 5 & 80 & 50 & 90 & 9 & - & - & - & - \\
\hline Lower level & 3 & 50 & 30 & 50 & 5 & - & - & - & - \\
\hline \multicolumn{10}{|l|}{ Experiments: } \\
\hline 1 (I)* & 5 & 80 & 50 & 90 & 9 & 2.0 & 2.05 & 0.88 & 0.903 \\
\hline $2(J)$ & 5 & 80 & 30 & 50 & 9 & 2.0 & 1.95 & 0.89 & 0.868 \\
\hline $3(\mathrm{~K})$ & 5 & 50 & 50 & 50 & 5 & 2.2 & 2.18 & 0.95 & 0.945 \\
\hline $4(\mathrm{~L})$ & 5 & 50 & 30 & 90 & 5 & 1.9 & 1.93 & 0.84 & 0.845 \\
\hline $5(\mathrm{M})$ & 3 & 80 & 50 & 50 & 5 & 2.1 & 2.13 & 0.90 & 0.905 \\
\hline $6(\mathrm{~N})$ & 3 & 80 & 30 & 90 & 5 & 1.9 & 1.88 & 0.81 & 0.805 \\
\hline $7(\mathrm{O})$ & 3 & 50 & 50 & 90 & 9 & 2.1 & 2.05 & 0.94 & 0.918 \\
\hline $8(\mathrm{P})$ & 3 & 50 & 30 & 50 & 9 & 1.9 & 1.95 & 0.86 & 0.883 \\
\hline
\end{tabular}

Legend: Highlights are highlighted in bold; the letters indicate different quantitative compositions of the culture medium.

Statistically significant coefficients of regression of model factors have the following meanings: for biomass yield $-b_{0}=1.842, b_{1}=0.013, b_{2}=-0.001, b_{3}=$ $0.009, b_{4}=-0.002, b_{5}=-0.006$; for rIL-7 yield $-b_{0}=0.810, b_{1}=0.006, b_{2}=-$ 0.001 , $b_{3}$ $=$

0.003 , $b_{4}=-0.001, b_{5}=-0.004$.

The equation of the model describing the process of deep cultivation of the recombinant producer in the optimized medium for the biomass and rIL-7 yield, respectively, had the forms:

$$
\begin{aligned}
& \bar{y}_{u 1}=1.842+0.013 x_{1}-0.001 x_{2}+0.009 x_{3}-0.002 x_{4}-0.006 x_{5}, \\
& \bar{y}_{u 2}=0.810+0.006 x_{1}-0.001 x_{2}+0.003 x_{3}-0.001 x_{4}-0.004 x_{5} .
\end{aligned}
$$

Obtained as a result of FFE $2^{5-2}$ regression equation relates the levels of influence of factors with the biomass and rIL-7 yield, respectively (within the studied area). The largest biomass of E. coli strain BL21 (DE3) 2.2 o.u. (experimental) and 2.18 o.u. (calculated), and the synthesis of rIL-7 $0.95 \mathrm{mg} / \mathrm{ml}$ (experimental) and $0.945 \mathrm{mg} / \mathrm{ml}$ (calculated) (Table 4) occurs when the medium K $\left(x_{l}=5 \mathrm{~g} / 1, x_{2}=50\right.$ $\left.\mathrm{ml} / \mathrm{l}, \quad x_{3}=50 \mathrm{ml} / \mathrm{l}, x_{4}=50 \mathrm{ml} / 1, x_{5}=5 \mathrm{~g} / \mathrm{l}\right)$. At the final output of the biosynthesis process, special effects are made by $\mathrm{x}_{1}$, and $\mathrm{x}_{5}$ is the concentration of $\mathrm{MgSO}_{4} \times 7 \mathrm{H}_{2} \mathrm{O}$ and $\mathrm{KH}_{2} \mathrm{PO}_{4}$.

The largest $E$. coli biomass yield [corresponded to 2.2 o.u. (experimental) and 2.18 o.u. (theoretical)], and the largest rIL-7 synthesis $0.95 \mathrm{mg} / \mathrm{m}$ (experimental) and $0.945 \mathrm{mg} / \mathrm{ml}$ (theoretical)] occurred when using a medium composition $\mathrm{K}\left(x_{1}=5 \mathrm{~g} / \mathrm{l}, x_{2}=50 \mathrm{ml} / \mathrm{l}, \quad x_{3}=50 \mathrm{ml} / 1, x_{4}=50 \mathrm{ml} / 1, x_{5}\right.$ $=5 \mathrm{~g} / \mathrm{l})$. More pronounced effect on the biosynthesis carried out process $\mathrm{x}_{1}$ and $\mathrm{x}_{5}$ factors: concentration of $\mathrm{MgSO}_{4} \times 7 \mathrm{H}_{2} \mathrm{O}$ and $\mathrm{KH}_{2} \mathrm{PO}_{4}$.

As a result of experiments aimed at optimization of the culture medium using the FFE plan we have obtained equations describing the amount of accumulated biomass and the synthesized rIL-7 in the deep culture depending on the quantitative composition of the mineral substances. Fig. 3 and 4 show comparison between theoretical and experimental data in terms of biomass and rIL-7 yields.

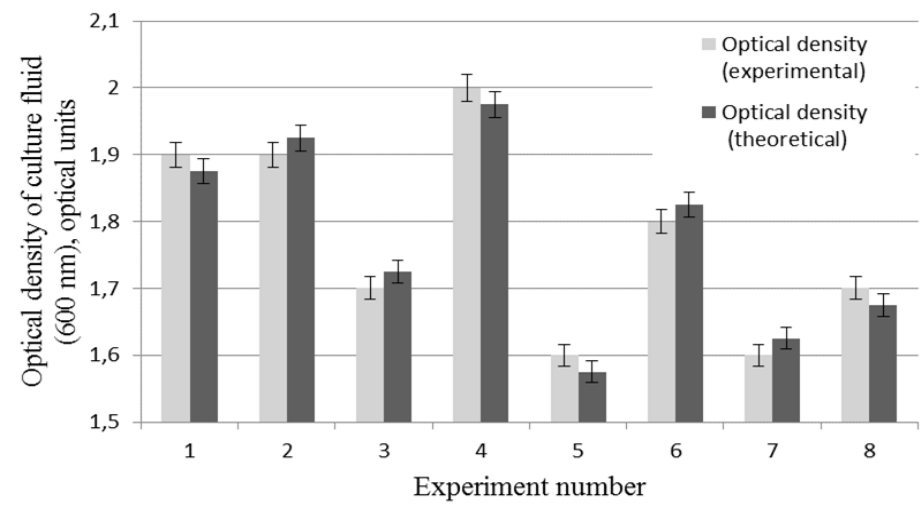

Figure 3 Dependence of the E. coli biomass yield on the quantitative composition of the culture medium (mineral components): 1 - composition I; 2 composition $\mathrm{J} ; 3$ - composition $\mathrm{K} ; 4$ - composition L; 5 - composition M; 6 composition $\mathrm{N} ; 7$ - composition $\mathrm{O} ; 8$ - composition $\mathrm{P}$

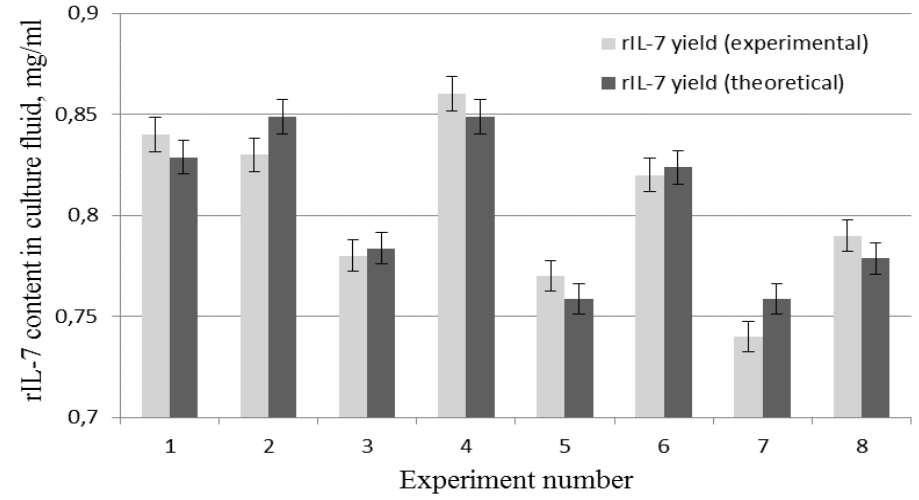

Figure 4 Dependence of rIL-7 yield on the quantitative composition of the culture medium (mineral components): 1 - composition I; 2 - composition J; 3 composition $\mathrm{K} ; 4$ - composition L; 5 - composition M; 6 - composition N; 7 composition $\mathrm{O} ; 8$ - composition $\mathrm{P}$

Table 3 Recommended composition of the culture medium for deep cultivation of E. coli strain, producer of rIL-7

\begin{tabular}{ll}
\hline Components & Quantity \\
\hline Peptone & $17 \mathrm{~g} / \mathrm{l}$ \\
\hline Yeast extract & $10 \mathrm{~g} / 1$ \\
\hline Lactose & $2 \mathrm{~g} / 1$ \\
\hline Glycerin & $5 \mathrm{ml} / 1$ \\
\hline Glucose & $0.5 \mathrm{~g} / 1$ \\
\hline D-maltose & $5 \mathrm{~g} / 1$ \\
\hline $\mathrm{MgSO}_{4} \times 7 \mathrm{H}_{2} \mathrm{O}$ & $5 \mathrm{~g} / 1$ \\
\hline$\left(\mathrm{NH}_{4}\right)_{2} \mathrm{SO}_{4}$ & $3.3 \mathrm{~g} / 1$ \\
\hline $\mathrm{KH}_{2} \mathrm{PO}_{4}$ & $6,8 \mathrm{~g} / 1$ \\
\hline $\mathrm{Na}_{2} \mathrm{HPO}_{4}$ & $7.1 \mathrm{~g} / 1$ \\
\hline $\mathrm{NaHCO}_{3}$ & $5 \mathrm{~g} / 1$ \\
\hline $\mathrm{Chloramphenicol}$ & $0.173 \mathrm{mg} / \mathrm{l}$ \\
\hline
\end{tabular}

On the basis of the FFE data an optimal quantitative composition of the organic and mineral components of the culture medium, in recalculation the solid components, for E. coli strain cultivations was determined (Table 3). As a result of carried out culture medium optimization the biomass yield has increased in 1.4 times, and the rIL-7 yield increased in 1.3 times compared to the base composition (Lutsenko et al., 2015)

Study of the influence of plant extracts and vitamin K1 on the level of biosynthesis of rIL-7

For the characterization of the obtained plant extracts at the first stage of the study it was necessary to determine the content of certain groups of biologically active substances, namely: proteins, carbohydrates, alkaloids. The choice of these substances for the characterization of plant extracts was carried out on the basis of the analysis of literature data and own experience in pharmacological studying of the respective plants (Veale $\boldsymbol{e t}$ al., 1989; Katoch $\boldsymbol{e t}$ al., 2012). The results of phytochemical characteristics of plant extracts are given in Table 4 . In the framework of this stage, the culture medium of an optimized composition was used; producer cultivation conditions were the same. 
Table 4 Phytochemical characteristic of plant extracts

\begin{tabular}{lcc}
\hline \multirow{2}{*}{ Biologically active substances } & \multicolumn{2}{c}{ Extract } \\
\cline { 2 - 3 } & Clivia miniata & $\begin{array}{c}\text { Zephyranthes } \\
\text { grandiflora }\end{array}$ \\
\hline Proteins, \% & 0.45 & 0.87 \\
\hline Carbohydrates, \% & 0.58 & 0.72 \\
\hline $\begin{array}{l}\text { Alkaloids (in terms of licorine), } \\
\%\end{array}$ & 0.06 & 0.08 \\
\hline
\end{tabular}

Legend: The arithmetic mean of the three values is given.

To assess the effect of plant extracts (range of concentrations of 0.1-5.0\%) and vitamin $\mathrm{K} 1$ (range of concentrations of $5-25 \mathrm{mg} / \mathrm{ml}$ ) on the growth of E. coli strain and the level of synthesis of rIL-7, the concentration was determined bacterial cells at the end of cultivation and the content of the target product in the culture liquid.

It should be noted that the literature describes the results of a series of experiments on the influence of vitamin $\mathrm{K} 1$ on the growth of shigella and staphylococci (Baronets et al., 2001), as well as the synthesis of the $C h$. trachomatis recombinant HSP-60 protein (Galkin et al., 2015). In the first case, positive results have been obtained: vitamin $\mathrm{K} 1$ increased the growth of pathogenic microorganisms. In the case of recombinant HSP-60 synthesis, the stimulating effect of the vitamin supplement in the concentration range of 5-25 $\mathrm{mg}$ per $1 \mathrm{ml}$ of the culture medium has been not obtained. Lack of influence on the biosynthetic processes of vitamin K1 could be due to high levels of lipophilicity of vitamin $\mathrm{K} 1$ and the complexity of maintaining its concentration in the culture medium at an appropriate level. It should also be noted that according to available data (Khalifa et al., 2018) lycorine, being one of the most studied biologically active substances of the family Amaryllidaceae plants, probably mediates the effect on growth and biosynthetic activity of the recombinant $E$. coli (Galkin et al., 2015). And lycorine is poorly soluble in water and organic solvents. Therefore, it is possible that the bioavailability of licorine from plant extracts for recombinant bacteria is poor. Based on the above, liposomal forms of vitamin K1 and plant extracts were used in our present study. Liposomes were prepared according to the modern method (Campani et al., 2014). The results of the relevant studies are shown in Table 5.

Table 5 Influence of plant extracts and vitamin K1 on the yield of E. coli biomass and rIL-7

\begin{tabular}{|c|c|c|c|c|}
\hline $\begin{array}{l}\text { Concentration of the } \\
\text { supplement to the } \\
\text { culture medium }\end{array}$ & $\begin{array}{l}\text { Option for the } \\
\text { supplement adding }\end{array}$ & $\begin{array}{l}\text { Concentration of } \\
\text { culture in experiment, } \\
\text { o.u. }\left(\mathrm{OD}_{600}\right)\end{array}$ & $\begin{array}{l}\text { Concentration of rIL-7 } \\
\text { in culture fluid, } \mathrm{mg} / \mathrm{ml}\end{array}$ & $\begin{array}{l}\text { Share of rIL-7 from } \\
\text { the total amount of } \\
\text { bacterial proteins, \% }\end{array}$ \\
\hline \multicolumn{5}{|l|}{ Clivia miniata extract } \\
\hline \multirow{2}{*}{$0.1 \%$} & Basic & 2.8 & 0.97 & 16 \\
\hline & Liposomal & 3.1 & 1.02 & 19 \\
\hline \multirow{2}{*}{$0.5 \%$} & Basic & 3.0 & 1.23 & 17 \\
\hline & Liposomal & 2.9 & 1.33 & 21 \\
\hline \multirow{2}{*}{$1.0 \%$} & Basic & 2.8 & 0.96 & 18 \\
\hline & Liposomal & 2.4 & 0.95 & 15 \\
\hline \multirow[b]{2}{*}{$5.0 \%$} & Basic & 2.3 & 0.89 & 9 \\
\hline & Liposomal & 2.2 & 0.82 & 8 \\
\hline \multicolumn{2}{|c|}{ Control (without extract and SPH) } & 2.2 & 0.95 & 12 \\
\hline \multicolumn{2}{|c|}{ Control (without extract, with SPH) } & 2.2 & 0.94 & 12 \\
\hline \multicolumn{5}{|c|}{ Zephyranthes grandiflora extract } \\
\hline \multirow[t]{2}{*}{$0.1 \%$} & Basic & 2.8 & 0.97 & 17 \\
\hline & Liposomal & 3.4 & 1.25 & 19 \\
\hline \multirow[t]{2}{*}{$0.5 \%$} & Basic & 3.3 & 1.25 & 18 \\
\hline & Liposomal & 3.0 & 1.19 & 22 \\
\hline \multirow[t]{2}{*}{$1.0 \%$} & Basic & 2.7 & 0.99 & 17 \\
\hline & Liposomal & 2.3 & 1.05 & 14 \\
\hline \multirow[t]{2}{*}{$5.0 \%$} & Basic & 2.1 & 0.88 & 9 \\
\hline & Liposomal & 2.1 & 0.74 & 8 \\
\hline \multicolumn{2}{|c|}{ Control (without extract and SPH) } & 2.2 & 0.95 & 12 \\
\hline \multirow{2}{*}{\multicolumn{2}{|c|}{$\begin{array}{l}\text { Control (without extract, with SPH) } \\
\text { Vitamin K1 }\end{array}$}} & 2.2 & 0.94 & 12 \\
\hline & & \multicolumn{3}{|c|}{ Vitamin K1 } \\
\hline \multirow[t]{2}{*}{$5 \mathrm{mg} / \mathrm{ml}$} & Basic & 2.4 & 0.95 & 15 \\
\hline & Liposomal & 2.4 & 1.01 & 17 \\
\hline \multirow[t]{2}{*}{$10 \mathrm{mg} / \mathrm{ml}$} & Basic & 2.5 & 0.96 & 17 \\
\hline & Liposomal & 2.6 & 1.21 & 18 \\
\hline \multirow[t]{2}{*}{$15 \mathrm{mg} / \mathrm{ml}$} & Basic & 2.5 & 0.96 & 17 \\
\hline & Liposomal & 2.8 & 1.29 & 22 \\
\hline \multirow[t]{2}{*}{$25 \mathrm{mg} / \mathrm{ml}$} & Basic & 2.6 & 0.92 & 18 \\
\hline & Liposomal & 2.8 & 1.33 & 21 \\
\hline Control (without extract an & $\mathrm{SPH})$ & 2.4 & 0.96 & 12 \\
\hline
\end{tabular}

$\begin{array}{lcc}\text { Control (without extract and SPH) } & 2.4 & 0.96 \\ \text { Legend: Average value of the parameter based on the results of three experiments. **The level of significant difference between the results of the experiment }\end{array}$

and control is $\mathrm{P}<0.05$. ${ }^{* * *}$ The level of the true difference between the results of the experiment and the control is $\mathrm{P}<0.01$.

It should be noted that for two investigated plant extracts, stimulating effect on culture growth and the content of recombinant protein was found in the range of concentrations of $0.1-1 \%$. In this case, when using normal extracts (the basic option), the best results were recorded when the extracts were added to the nutrient medium at a concentration of $0.5 \%$. At the same time, when adding liposomal extracts, the highest result was fixed at a concentration of $0.1 \%$ (Fig 5 8). Such data indicate that the use of liposomal forms of extracts influenced the bioavailability of herbal biologically active substances for bacterial cells. However, it should be noted that it is hardly advisable to recommend the use of liposomal admission for further application, because, for example, in the case of addition of Clivia miniata extract (0.1-0.5\%) to the culture medium, the growth of rIL-7 yield was observed only in 1.05-1.08 times (Fig. 6). And in the case of the addition of Zephyranthes grandiflora extract to culture medium in a concentration of $0.1 \%$ (liposomal form) and in concentration of $0.5 \%$ (baseline), the results were comparable (Fig. 8). In general, the use of phytosupplements to the culture medium has increased the content of the target product in the culture fluid by 1.3-1.4 times. It should also be noted that for both the plant extracts in the range of $0.1-1.0 \%$, an increase in the proportion of the target product among all proteins of the bacterial cell was observed (Figs. 6 and 8). Such results, in our opinion, are quite positive and can be used in further producer cultivation.

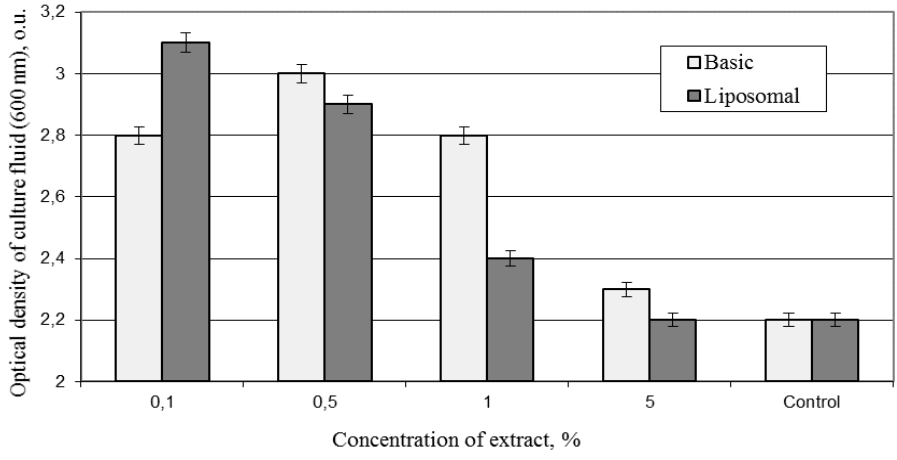

Figure 5 Dependence of the E. coli biomass concentration on the Clivia miniata extract content in the culture medium 


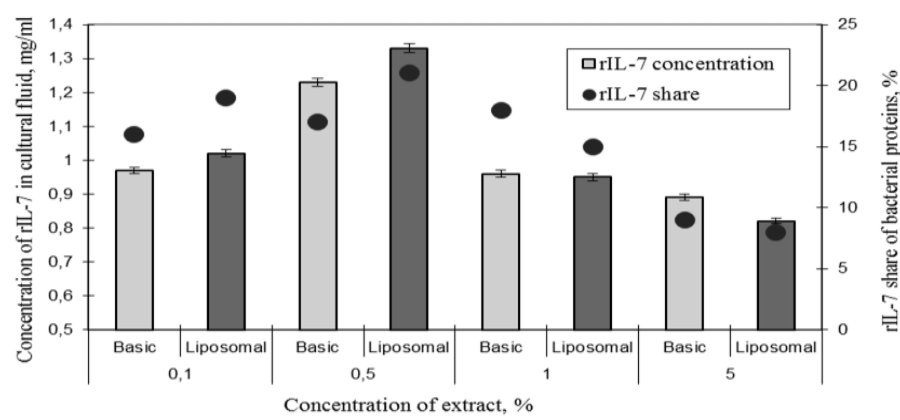

Figure 6 Dependence of the rIL-7 content on the Clivia miniata extract content in the culture medium

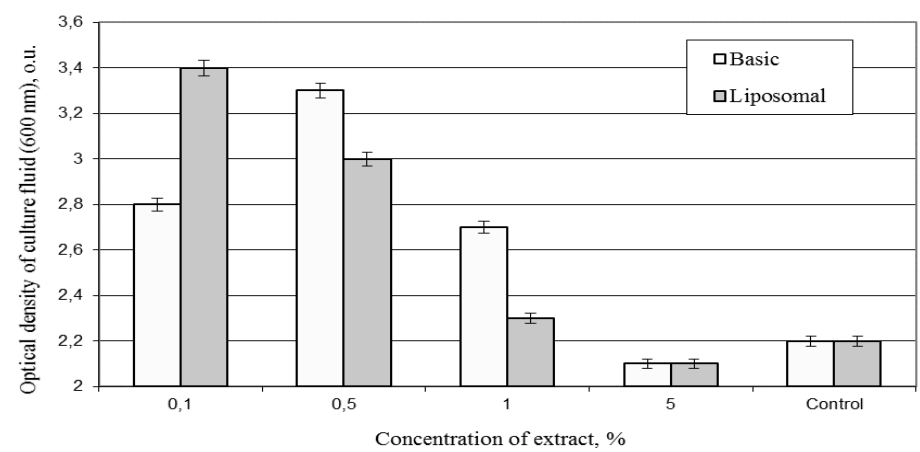

Figure 7 Dependence of the E. coli biomass concentration on the Zephyranthes grandiflora extract content in the culture medium

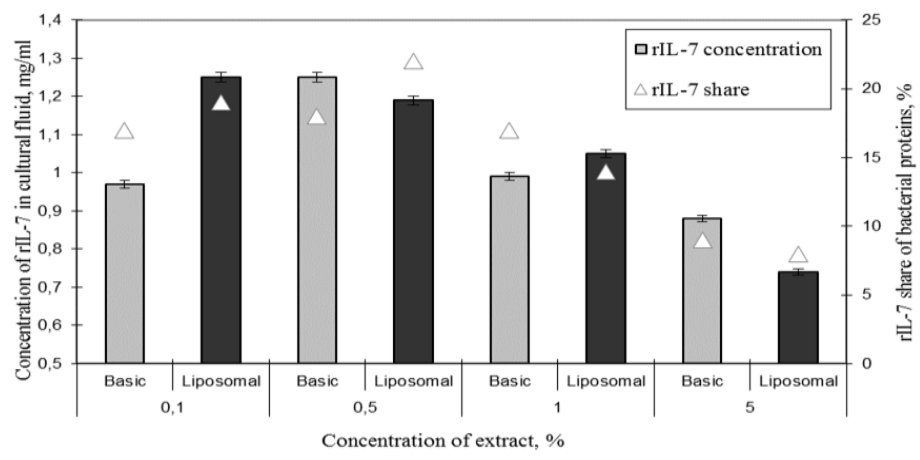

Figure 8 Dependence of the rIL-7 content on the Zephyranthes grandiflora extract content in the culture medium

Separately, it should be noted that when using relatively large concentrations of phytoextracts, inhibitory effects on growth and biosynthetic properties of the bacterial producer were recorded. In general, the literature describes the inhibitory effect of this substance on the processes of protein synthesis in higher plants, animals and algae, as well as a variety of effects (inhibiting or stimulating) on the growth of different yeasts (Galkin et al., 2015; Vrijsen et al., 1986; Poyedinok et al., 2018). The ranges of inhibitory and stimulating effects of plant extracts are consistent with known data (Galkin et al., 2015) Additionally, it should be noted that with a probable increase in the availability of herbal biologically active substances for a bacterial cell, there was a decrease in the boundary of toxic effects of phytoextracts (Figs 5-8). Such data further indicate the inappropriate use of liposomal forms of plant extracts as a way to increase the biosynthetic properties of the bacterial producer.

Separate analysis has to be done regarding results of bacterial biomass and rIL-7 yield depending on vitamin K1 concentration in the culture medium (Fig. 9 and 10). When normal vitamin K1 was added to the culture medium, no stimulating effect on either the growth of culture or the target product synthesis was observed. And it completely correlates with previously published data on the properties of a recombinant producer of the Ch. trachomatis HSP-60 (Galkin et al., 2015). At the same time, for the use of vitamin K1 liposomal form there was a gradual increase in both the yield of biomass (1.2 times) and the content of the target product (1.34-1.39 times). Such results indicate that the use of liposomal form of vitamin has significantly increased its availability for a bacterial cell, and the level of increase of rIL-7 content in the culture fluid in case of liposomal application makes it possible to recommend the incorporation of liposomal form of vitamin $\mathrm{K} 1$ into the culture medium.

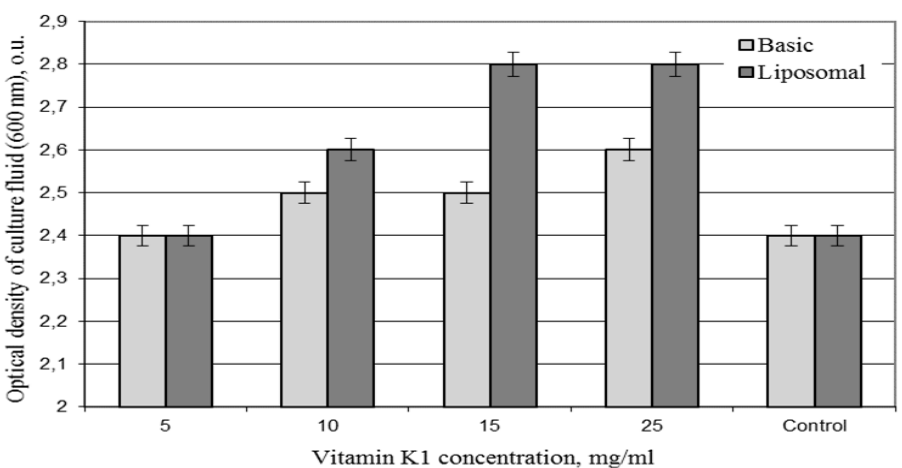

Figure 9 Dependence of the E. coli biomass concentration on the vitamin K1 content in the culture medium

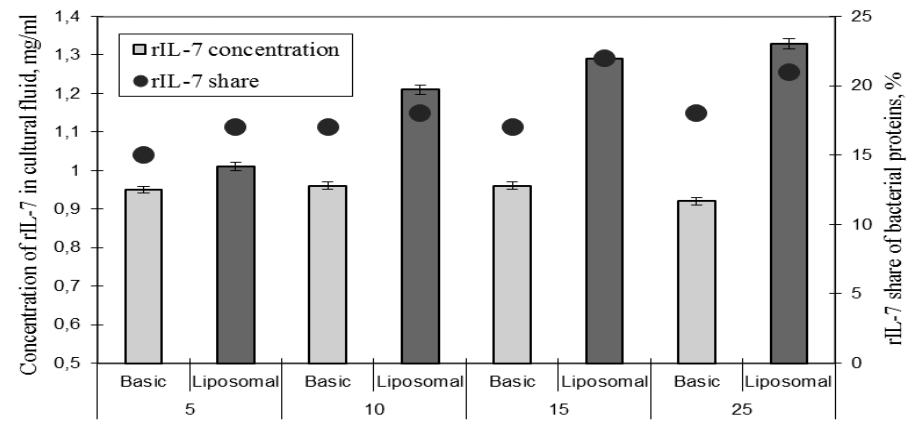

Vitamin $\mathrm{K} 1$ concentration, $\mathrm{mg} / \mathrm{ml}$

Figure 10 Dependence of the rIL-7 content on the vitamin K1 content in the culture medium

Study of the mechanisms of the plant extracts influence on the biosynthetic activity of the recombinant producer

Since previous studies have shown the effectiveness of the natal lily and pink rain lily extracts as supplements to the culture medium of recombinant $E$. coli, the producer of rIL-7, it was advisable to investigate the mechanisms of phytoextracts biological activity. In papers (Pererva et al., 2012; Pererva et al., 2010), it was found that, biological active substances of Ungernia victoris extract interact with $E$. coli cells, and at least one of the targets is located in the plasma membrane of the bacterial cell. This information is important given that Ungernia victoris, as well as Clivia miniata and Zephyranthes grandiflora belongs to the Amaryllidaceae family. Therefore, the starting point for our further research was the assumption about the possibility of interaction of the plant extracts components with E. coli surface structures. To study the mechanisms of such interaction, we used a method similar to the phagocytosis of bacteria which allows assessing the structural and physiological state of the bacterium cell wall when it interacts with different substances (Pererva et al., 2012). In the case of interaction between the test substances and certain surface structures of the bacterium (in particular, the lipopolysaccharides and proteins of the outer membrane of the cell membrane), there will be a decrease in the level of bacteriophages adsorption on the cell surface and, accordingly, a decrease in the efficiency of bacteriophage sowing. Since the adsorption of bacteriophages occurs in a specific way, when interacting with known surface structures of a bacterial cell, this approach can provide valuable information on the molecular mechanisms of plant extracts interaction with $E$. coli cells.

In the planning of these experiments, we selected six bacteriophages with different molecular targets on E. coli surface, namely: T7 (absorbed by lipopolysaccharides), $\lambda$ (absorbed by LamB protein), Ox2 (absorbed by the OmpA protein), Ox2h12 (absorbed by OmpA and OmpC proteins), TuIb (absorbed by the OmpC protein) and T2 (absorbed by the OmpF protein) (Datta et al., 1977). The results of studying the effect of plant extracts on the sowing of different bacteriophages are presented in Table 6 .

Table 6 Effect of plant extracts on the efficiency of bacteriophage sowing

\begin{tabular}{|c|c|c|c|c|c|c|c|}
\hline Extract origin & \multicolumn{6}{|c|}{ Bacteriophages } & F-test \\
\hline Zephyranthes grandiflora & $98 \pm 5$ & $104 \pm 5$ & $99 \pm 8$ & $65 \pm 8$ & $74 \pm 8$ & $92 \pm 4$ & $\beta>0,95$ \\
\hline
\end{tabular}

Legend: The table shows the average values and their standard deviations $(\mathrm{M} \pm \mathrm{m})$, as a percentage, relative to the control; each experiment is executed in 4 repetitions. 
Based on obtained results bacteriophages can be divided into two groups: the $1^{\mathrm{s}}$ group contains $\mathrm{T} 7, \lambda$ and Ox 2 bacteriophages, and the $2^{\text {nd }}$ group - Ox $2 \mathrm{~h} 12$, Tulb and T2 bacteriophages. For the $1^{\text {st }}$ group of bacteriophages, the average value of sowing efficiency is $105.3 \pm 6 \%$, and for the $2^{\text {nd }}$ group $-84.5 \pm 5 \%$. And it indicates the statistically significant differences between these groups of bacteriophages (when evaluated by the Student $t$-criterion $\mathrm{P}<0.01$, and F-Fisher's criterion $\beta>0.95$ ). Note that for each plant extract, there were also statistically significant differences in the efficiency of seeding bacteriophages of both groups Thus, it can be argued that in the presence of both extracts Ox $2 \mathrm{~h} 12$, Tulb and T2 bacteriophages significantly reduce the sowing efficiency compared with the control. It is known that the receptors of these bacteriophages are the pores of the bacterial outer membrane (Datta et al., 1977). Most likely, the decrease in the efficiency of sowing for these bacteriophages is due to the interaction of substances from the herbal extracts with phage bacterial cell receptors.

Interesting results were obtained in the case of the both phytoextracts effect on the interaction of bacteria with Ox $2 \mathrm{~h} 12$ bacteriophages in comparison with similar results for Tulb bacteriophage. As is known, Ox $2 \mathrm{~h} 12$ bacteriophages have two cellular receptors, namely OmpA and OmpC proteins, while the Tuib bacteriophages interact only with OmpC protein. Thus, in the case of both bacteriophages $\mathrm{Ox} 2 \mathrm{~h} 12$ and TuIb, there was a decrease in sowing efficiency (in the case of Zephyranthes grandiflora it was more pronounced). At the same time, no changes were made in the case of the use of Ox2 bacteriophages, which interact with the bacterial OmpA protein. Such results are likely to indicate the presence of substances in plant extracts competing with OmpC protein for binding sites and not affecting the interaction with OmpA protein. An alternative potential explanation may be to change the level of expression of various surface bacterium proteins under the action of certain substances in the culture medium. At the same time, the results of other authors (Van Alphen et al., 1977; Kawaji et al., 1979; Russo et al., 1993) regarding the study of the mechanisms of OmpA, $\mathrm{OmpC}$, and $\mathrm{OmpF}$ proteins expression by $E$. coli are proved in favor of the proposed by us nature of the interaction of phytosubstances with bacterial surface structures. In particular, it was found that a change in the expression ratio of these proteins can be observed when added to the culture medium excess amounts of sodium and potassium chlorides $(300 \mathrm{mM})$ or sucrose $(600 \mathrm{mM})$. Based on the results of the plant extracts phytochemical study, as well as the literature data (Galkin et al., 2015; Datta et al., 1977; Van Alphen et al., 1977; Kawaji et al., 1979; Russo et al., 1993), it is illogical to assume that there are substances in the extracts that could critically alter the expression of OmpA, OmpC and $\mathrm{OmpF}$ proteins in E. coli cells.

\section{CONCLUSIONS}

The quantitative composition of the culture medium was optimized for the cultivation of a recombinant $E$. coli strain - producer of recombinant human IL-7. The determined rational ratio of organic and mineral components allowed increasing the yield of biomass by 1.4 times and the synthesis of rIL-7 by 1.3 times compared to the base composition.

It was proved the stimulating effect of Clivia miniata and Zephyranthes grandiflora extracts, as well as liposomal form of vitamin $\mathrm{K} 1$, as additives to the culture medium for the recombinant $E$. coli strain: in the range of $0.5-1.0 \%$ for phytoextracts and $15-25 \mathrm{mg} / \mathrm{ml}$ for vitamin $\mathrm{K} 1$. Increasing the concentration of extracts up to $5.0 \%$ resulted in growth inhibition and biosynthetic activity. The use of the liposomal form of phytoextracts increased bioavailability of biologically active substances for the bacterial cell; however, the difference in the growth of the synthesized rIL-7 between the liposomal and conventional forms of extracts was insignificant. It should be noted that increasing bioavailability contributed to a decrease in the boundary of inhibitory effects. So, for further application in industrial biosynthesis, the conventional forms of phytoextracts have to be recommended. And vitamin K1 it is more expedient to add in liposomal form, because when using the usual, no stimulating effect was observed. In general, with the addition of phytoextracts to the culture medium, the rIL-7 yield increased in 1.3-1.4 times, and with the addition of vitamin K1 the rIL-7 yield increased in 1.34-1.39 times.

Biologically active substances of the investigated extracts interact with the surface structures of E. coli cell, namely, porins - OmpC and OmpF proteins. Substances such as carbohydrates and mineral salts contained in plant extracts do not have a significant effect on the level of expression of various pores and porous-like proteins by E. coli cells. The mechanism of this interaction, with a high probability, is associated with the competition of substances of plant origin for binding to cellular receptors on the surface of a bacterial cell.

\section{REFERENCES}

Adinarayana, K., \& Ellaiah, P. (2002). Response surface optimization of the critical medium components for the production of alkaline protease by a newly isolated Bacillus sp. J Pharm Pharm Sci, 5(3), 272-278.

Ahmed, N., Abbas, R., Khan, M. A., Bashir, H., Tahir, S., \& Zafar, A. U. (2018). Enhancing recombinant interleukin-6 production yield by fermentation optimization, two-step denaturing, and one-step purification. Biotechnology and applied biochemistry, 65(3), 490-496. https://doi.org/10.1002/bab.1588
Alphen, W. V., \& Lugtenberg, B. (1977). Influence of osmolarity of the growth medium on the outer membrane protein pattern of Escherichia coli. Journal of bacteriology, 131(2), 623-630.

Baronets, N. G., Adlova, G. P., \& Melnikova, V. A. (2001). Effect of the herbal extracts on the growth of microorganisms. Journal of Microbiology, 5, 71-72 (in Russian).

Boiko, M. V., Patyka, N. V., Shulga, S. M., Tigunova, O. O., \& Andriiash, H. S. (2018). Mathematical modelling of optimization nutrient medium composition for entomopathogenic bacteria strain Bacillus thuringiensis 87/3 cultivation. Biotechnologia Acta, 11(2), 40-46. https://doi.org/10.15407/biotech11.02.040

Campani, V., Marchese, D., Pitaro, M. T., Pitaro, M., Grieco, P., \& De Rosa, G (2014). Development of a liposome-based formulation for vitamin K1 nebulization on the skin. International journal of nanomedicine, 9, 1823. https://doi.org/10.2147/IJN.S58365

Datta, D. B., Arden, B. E. R. N. H. A. R. D., \& Henning, U. (1977). Major proteins of the Escherichia coli outer cell envelope membrane as bacteriophage receptors. Journal of bacteriology, 131(3), 821-829.

Galkin, O. Y., \& Kotov, A. G. (2011). Study of biologically active substances content in herbal preparation for the treatment and prevention of alopecia. Ukrainian Journal of Clinical and Laboratory Medicine, 6(1), 60-63.

Galkin, O. Y., Lutsenko, T. M., Gorshunov, Y. V., \& Motronenko, V. V. (2017). Development of the method for microbiological purity testing of recombinant human interleukin-7-based product. The Ukrainian Biochemical Journal, 89(3), 52-59. https://doi.org/10.15407/ubj89.03.052

Galkin, O. Yu., Gorshunov, Yu. V., Besarab, O. B., Lutsenko, T. M., \& Grishyna, A. S. (2015). Effect of plant supplements to nutrient media on biosynthesisof recombinant protein by Escherichia coli. Visnyk of Zaporizhzhya National University. Biological Sciences, 1, 184-194 (in Russian).

Katoch, D., Kumar, S., Kumar, N., \& Singh, B. (2012). Simultaneous quantification of Amaryllidaceae alkaloids from Zephyranthes grandiflora by UPLC-DAD/ESI-MS/MS. Journal of pharmaceutical and biomedical analysis, 71,187-192. https://doi.org/10.1016/j.jpba.2012.08.001

Kawaji, H., Mizuno, T., \& Mizushima, S. (1979). Influence of molecular size and osmolarity of sugars and dextrans on the synthesis of outer membrane proteins $\mathrm{O}$ 8 and O-9 of Escherichia coli K-12. Journal of Bacteriology, 140(3), 843-847.

Khalifa, M. F., Attia, E. Z., Fahim, J. R., \& Kamel, M. S. (2018). An overview on the chemical and biological aspects of lycorine alkaloid. Journal of advanced Biomedical and Pharmaceutical Sciences, 1(2), 41-49. https://doi.org/10.21608/jabps.2018.4088.1016

Khalilzadeh, R., Shojaosadati, S. A., Maghsoudi, N., Mohammadian-Mosaabadi, J., Mohammadi, M. R., Bahrami, A., ... \& Naderimanesh, H. (2004). Process development for production of recombinant human interferon- $\gamma$ expressed in Escherichia coli. Journal of Industrial Microbiology and Biotechnology, 31(2), 63-69. https://doi.org/10.1007/s10295-004-0117-x

Lomboeva, S. S., Tanhaeva, L. M., \& Olejnikov, D. N. (2008). Methods of quantitative determination of total flavonoid content in the aerial part ortiliya sided (Orthilia secunda (L.) House). Chemistry of plant raw material, 2, 65-68.

Lutsenko, T. N., Galkin, A. Yu. (2015). Substantiation of biotechnological approaches of producing interleukin-7 recombinant human. Proceedings of $B S T U, 4(177), 188-197$ (in Russian).

Omotani, S., Tani, K., Nagai, K., Hatsuda, Y., Mukai, J., \& Myotoku, M. (2017). Water soluble vitamins enhance the growth of microorganisms in peripheral parenteral nutrition solutions. International journal of medical sciences, 14(12), 1213. https://doi.org/10.7150/ijms.21424

Pal, D., Tripathy, R. K., Teja, M. S., Kumar, M., Banerjee, U. C., \& Pande, A. H. (2018). Antibiotic-free expression system for the production of human interferonbeta protein. 3 Biotech, 8(1), 36. https://doi.org/10.1007/s13205-017-1056-3

Pererva, T. P., Kobozev, Y. A., Moisa, L. N., Dvornik, A. S., Miryuta, A. Y., Mozhylevska, L. P., \& Kunakh, V. A. (2012). Increasing of Escherichia coli recombinant strains productivity by means of nutrient medium enrichment with addition of plant origin. Biotechnologia Acta, 5(1), 42.

Pererva, T. P., Miriuta, A., Morsa, L. N., Mozhilevskaia, L. P., \& Kunakh, V. A. (2010). Interaction of Ungernia victoris, Rhodiola rosea and Polyscias filicifolia plant extracts with bacterial cells. TSitologiia i genetika, 44(4), 34-40. (in Russian).

Poyedinok, N., Mykchaylova, O., Sergiichuk, N., \& Negriyko, A. (2018). Realization of Macromycete Photoinduced Growth Activity: Influence of Cultivation Ways and the Concentration of Carbon and Nitrogen. Innovative

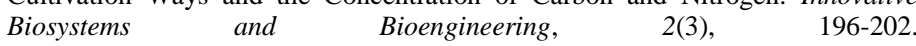
https://doi.org/10.20535/ibb.2018.2.3.134629

Russo, F. D., Slauch, J. M., \& Silhavy, T. J. (1993). Mutations that affect separate functions of OmpR the phosphorylated regulator of porin transcription in Escherichia coli. Journal of molecular biology, 231(2), 261-273. https://doi.org/10.1006/jmbi.1993.1281

Semeniuk, S., Shybetskyy, V., Povodzinskiy, V., \& Kostyk, S. (2018). Assessment of Critical Parameters of the Cultivating Process in Biotechnology of Active Pharmaceutical Ingredients. Innovative Biosystems and Bioengineering, 2(2), 118-124. (in Ukrainian). https://doi.org/10.20535/ibb.2018.2.2.123469

Sengupta, P., Meena, K., Mukherjee, R., Jain, S. K., \& Maithal, K. (2008) Optimized conditions for high-level expression and purification of recombinant 
human interleukin-2 in E. coli. Indian Journal of Biochemistry \& Biophysics, 45,

91-97.

Singh, V., Haque, S., Niwas, R., Srivastava, A., Pasupuleti, M., \& Tripathi, C. K. M. (2017). Strategies for fermentation medium optimization: an in-depth review. Frontiers in microbiology, 7, 2087. https://doi.org/10.3389/fmicb.2016.02087

Spaepen, S., Vanderleyden, J., \& Remans, R. (2007). Indole-3-acetic acid in microbial and microorganism-plant signaling. FEMS microbiology reviews, 31(4), 425-448. https://doi.org/10.1111/j.1574-6976.2007.00072.x

Studier, F. W. (2005). Protein production by auto-induction in high-density shaking cultures. Protein expression and purification, 41(1), 207-234 https://doi.org/10.1016/j.pep.2005.01.016

Veale, D. J. H., Oliver, D. W., Arangies, N. S., \& Furman, K. I. (1989)

Preliminary isolated organ studies using an aqueous extract of Clivia miniata leaves. Journal of ethnopharmacology, 27(3), 341-346. https://doi.org/10.1016/0378-8741(89)90008-1

Vrijsen, R., Berghe, D. V., Vlietinck, A. J., \& Boeye, A. (1986). Lycorine: a eukaryotic termination inhibitor? Journal of Biological Chemistry, 261(2), 505507.

Wang, H., Wang, F., Wang, W., Yao, X., Wei, D., Cheng, H., \& Deng, Z. (2014) Improving the expression of recombinant proteins in $E$. coli BL21 (DE3) under acetate stress: an alkaline $\mathrm{pH}$ shift approach. PloS one, 9(11), e112777. https://doi.org/10.1371/journal.pone.0112777

Wang, J. K., Chiu, H. H., \& Hsieh, C. S. (2009). Optimization of the medium components by statistical experimental methods to enhance nattokinase activity. Fooyin Journal of Health Sciences, 1(1), 21-27. https://doi.org/10.1016/S1877 8607(09)60004-7

Zhong, Y., Yang, L., Guo, Y., Fang, F., Wang, D., Li, R., ... \& Xiao, W. (2014)

High-temperature cultivation of recombinant Pichia pastoris increases endoplasmic reticulum stress and decreases production of human interleukin-10 Microbial cell factories, 13(1), 163. https://doi.org/10.1186/s12934-014-0163-7 